\title{
Nomenclatural notes on the family Smilacaceae in Thailand
}

\author{
Pornchai Kladwong ${ }^{1}$, Pranom Chantaranothai ${ }^{1}$ \& David A. Simpson ${ }^{2,3}$
}

Summary. A nomenclatural synopsis of 11 of the 28 Smilax species recorded in Thailand (S. bracteata, S. calophylla, S. corbularia, S. davidiana, S. extensa, S. hemsleyana, S. luzonensis, S. myosotiflora, S. myrtillus, S. perfoliata and S. prolifera) is presented. Three names, $S$. helferi var. maingayana, S. microchina and $S$. ocreata are placed into synonymy of S. luzonensis, S. davidiana, and S. perfoliata, respectively. Smilax prolifera is reinstated. Ten taxa, S. calophylla, S. extensa, S. helferi, S. helferi var. maingayana, S. hemsleyana, S. myosotiflora, S. myrtillus, S. ocreata, S. stenopetala and S. woodii are lectotypified.

Key Words. Lectotypification, reinstatement, Smilax, synonymy, taxonomy.

\section{Introduction}

Smilacaceae Vent. is a monogeneric family belonging to order Liliales, that is widely distributed mainly in tropical and subtropical regions of America, Africa and Asia. The family comprises two genera: Smilax L. is the largest, with c.300 species, while Heterosmilax Kunth has 10 - 12 species (Heywood et al. 2007; Mabberley 2008). Recently, it has been suggested that Heterosmilax is placed into Smilax, based on morphological and molecular data (Cameron \& Fu 2006; Chen et al. 2006; Qiu et al. 2013a; Judd et al. 2016).

In Thailand, 27 species (30 taxa) were recognised by Koyama (1975). A new Smilax species was later found in north-eastern Thailand (Moore et al. 2008), resulting in 28 species (31 taxa) enumerated for the country in total. Ongoing revisionary studies of the family for Thailand by the authors, which include comparisons with the work of Koyama $(1983,1984)$, Rae (1994), Chen \& Koyama (2000), Dassanayake (2000) and Qiu et al. (2013b), have examined the circumscription of species, together with associated nomenclatural problems. The present work aims to provide nomenclatural actions intended to resolve these various problems in the Thai taxa.

\section{Materials and Methods}

This study is largely based on the examination of specimens from India, China, Japan, Philippines, IndoChina, Myanmar, Thailand and the Malay Peninsula which are deposited in $\mathrm{A}, \mathrm{BK}, \mathrm{BKF}, \mathrm{BM}, \mathrm{BO}, \mathrm{DAO}, \mathrm{E}$, GH, HN, HNU, K, L, NY, P, PRC, SING, TCD, TI and US. Field observations in Thailand have also been made. Specimens were examined using a Nikon SMZ445 stereomicroscope. Nearly all the specimens cited here have been examined and are indicated by '?.

\section{Nomenclatural synopsis of Thai Smilax}

1. Smilax bracteata C. Presl (1827: 131). Type: Philippines, Luzon, Haenke s.n. (holotype PRC! [PRC450457]).

Smilax stenopetala A. Gray (1858: 412). Type: Japan, Kiu-siu (Kyushu), Kagoshima Bay, ơo, Wright 312 (lectotype GH! [00030109], selected here; isolectotypes GH! [00056356], US! [US00092046]).

NOTES. The original protologue of Smilax stenopetala was described by Gray (1858) based on Wright 312 from Kiu-siu (=Kyushu), Japan housed in GH and US. We have examined these specimens carefully and selected sheet 00030109 at $\mathrm{GH}$ as the lectotype because the specimen has more mature leaves, fruits and male flowers.

The lectotype sheet has two localities indicated: Kagoshima Bay and Hakodate, Hokkaido, both of which are cited in the protologue by Gray (1858).

There are two specimens of Wright 312 in $\mathrm{K}$ (K000820664, K000820666) that were collected from the Loo-Choo Is. (present-day Ryuku Is.). Loo-Choo was an independent kingdom until it was annexed by

\footnotetext{
Accepted for publication 16 May 2018. Published online 9 June 2018

1 Department of Biology and Centre of Excellence on Biodiversity (BDC), Faculty of Science, Khon Kaen University, Khon Kaen, 40002, Thailand. e-mail: pranom@kku.ac.th

2 Royal Botanic Gardens, Kew, Richmond, Surrey, TW9 3AB, UK.

3 Botany Department, Trinity College Dublin, Dublin 2, Ireland.
} 
Japan in 1879 and it seems unlikely that Wright would treat them as the same locality as Kiu-Siu. Therefore, without evidence that the locality on the label is incorrect, the material from Loo-Choo is not treated here as isolectotype material.

2. Smilax calophylla Wall. ex A. DC. (Candolle 1878: 60). Type: Singapore, Oct. 1822, +, Wallich 5131 (lectotype K-W! [K001104886], selected here; isolectotype $\mathrm{P}$ ! [P00686979]).

NOTES. The original protologue of Smilax calophylla was based on Wallich 5131 (Candolle 1878) and that has two duplicates. We selected sheet K001104886 at K-W as the lectotype because it has complete female inflorescences and mature fruits, while the sheet at $\mathrm{P}$ is without these characters.

3. Smilax corbularia Kunth (1850: 262). Type: Vietnam, Cochinchina, Loureiro s.n. (P, fide Koyama (1983)).

Smilax woodii Merr. (Merrill 1922: 162). Smilax corbularia var. woodii (Merr.) T. Koyama (1960: 15). Type: Malaysia, Sabah, Sandakan, Oct. 1920, ô, Wood 1097 (lectotype K! [K000292101], selected here; isolectotypes A! [A00030120], P! [P00686996], US! [US00092052]).

NOTES. Wood 1097 is mentioned in the original protologue of Smilax woodii (Merrill 1922). However, Wood's collection has four duplicates. Therefore, we select sheet K000292101 at K as the lectotype because it has more leaves and male flowers which are in good condition.

4. Smilax davidiana A. DC. (Candolle 1878: 104). Type: China, Guangxi, $q$, David s.n. (holotype P! [P00686782]).

Smilax microchina T. Koyama (1963: 15), synon. nov. Type: Thailand, Loei, Phu Kradueng, 10 July 1959, Th. Sørensen, K. Larsen $\mathcal{E}$ B B. Hansen 7465 (holotype DAO! [DAO000466230]).

NOTES. Smilax microchina is distinctive on account of its umbellate inflorescence which has $4-7$ flowers per umbel with $2-5 \mathrm{~cm}$ long leaf-blades and a very short or wanting tendril. These characters were used to separate this species from $S$. davidiana, which has more than 10 flowers per umbel with leaf-blades 5 $12 \mathrm{~cm}$ long and a tendril length of $0-12 \mathrm{~cm}$. (Koyama 1975). On examination of type material of S. microchina and specimens from Phu Kradueng, the type locality of $S$. microchina, we found that the umbels of this species have $4-10$ flowers, leaf-blades 2 -
$15 \mathrm{~cm}$ long and a tendril length of $0-15 \mathrm{~cm}$. These characters show a range of variation that encompasses both $S$. davidiana and $S$. microchina. Therefore, we conclude that $S$. microchina should be regarded as conspecific with S. davidiana.

5. Smilax extensa Wall. ex Hook. f. (Hooker 1892: 309). Type: Malaysia, Penang, §, Wallich 5126B (lectotype $\mathrm{K}-\mathrm{W}$ ! [K001104872], selected here; isolectotypes BM!, $\mathrm{K}$ !-3 sheets [K000292127, K000292128, K000292223]).

NOTES. Wallich 5126B is mentioned in the original description of Smilax extensa by Hooker (1892). However, Wallich's collection has four duplicates. Therefore, we select the sheet K001104872 at K as the lectotype because it has many male flowers and leaves.

6. Smilax hemsleyana Craib (1912: 409). Smilax zeylanica subsp. hemsleyana (Craib) T. Koyama (1975: 218). Type: Thailand, Chiang Mai, Doi Suthep, 11 April 1909, + , Kerr 596 (lectotype K! [K000292111], selected here; isolectotypes BM!-3 sheets, K!-2 sheets [K000292110, K000292112]).

NOTES. Kerr 596 is mentioned in the original protologue of Smilax hemsleyana by Craib (1912). However, this collection has six duplicates. Therefore, we select K000292111 at K as the lectotype because it has female flowers while the isolectotypes have fruits and young shoots.

7. Smilax luzonensis C. Presl (1827: 131). Type: Philippines, Luzon, Haenke s.n. (PRC, fide Koyama (1983)).

Smilax helferi A. DC. (Candolle 1878: 176). Type: Malay Peninsula, §, Griffith 5425 (lectotype K! [K000292125], selected here).

Smilax helferi var. maingayana A. DC. (Candolle 1878: 176), synon. nov. Type: Malaysia, 23 July 1866, §゚ㅇ, Maingay 1696 (lectotype K! [K000292121], selected here; isolectotype K! [K000292122]).

NOTES. Griffith 5425 was cited in the original protologue of Smilax helferi (Candolle 1878). K000292125 is selected as the lectotype because it has many male flowers and leaves which are in good condition. The original description of Smilax helferi var. maingayana was made by Candolle (1878) based on Maingay 1696 but the collection has two duplicates and, therefore, we designate K000292121 as the lectotype because it has many female flowers. 
8. Smilax myosotiflora A. DC. (Candolle 1878: 65). Type: Indonesia, §, Spanoghe s.n. (lectotype K! [K000292103], selected here).

NOTES. Of the two original collections, Millett s.n. (K) and Spanoghe s.n. (K), the latter is the best preserved and has many complete male inflorescences and a number of mature leaves.

9. Smilax myrtillus A. DC. (Candolle 1878: 106). Smilax rigida var. myrtillus (A. DC.) T. Koyama (1963: 74). Smilax rigida subsp. myrtillus (A. DC.) T. Koyama (1971: 173). Type: India, Khasia, +, Hooker $\mathcal{E}^{2}$ Thomson 5 (lectotype K! [K000939180], selected here; isolectotypes GH! [0030115], K! 5-sheets [K000939181, K000939182, K000939183, K000939184, K000939185], P! [P00686834], TCD! [TCD0018100]).

NOTES. Griffith 5453 and Hooker $\mathcal{E}$ Thomson 5 were cited in the original protologue of Smilax myrtillus (Candolle 1878), although the latter was incorrectly cited as Hooker $\mathcal{E}$ Thomson 3 in the first publication. Hooker $\mathcal{E}^{2}$ Thompson 5 has six duplicates in $\mathrm{K}$, and one each in GH, P and TCD. The sheet K000939180 at K is selected as the lectotype because it has complete stems and flowering branches and includes female flowers and fruits which are in good condition.

10. Smilax perfoliata Lour. (Loureiro 1790: 622). Type: Vietnam, Cochinchina, Loureiro s.n. (P, fide Koyama (1983)).

Smilax ocreata A. DC. (Candolle 1878: 191). Type: India, Uttar Pradesh, Kumaon, đ̊, Strachey $\mathcal{E}^{2}$ Winterbottom 5 (lectotype K! [K000820890], selected here).

NOTES. Smilax perfoliata was published and based on a Loureiro specimen that he collected from Vietnam. The original protologue explains that this species has an axillary umbellate inflorescence (Loureiro 1790). Smilax ocreata was proposed by Candolle (1878) but this species was treated as a synonym of $S$. perfoliata by Merrill (1935), Koyama (1960, 1975 \& 1983) and Rae (1994). Recently, S. ocreata was separated as a species in its own right by Chen \& Koyama (2000) and Dassanayake (2000). On examination of type material of $S$. ocreata and specimens gathered during fieldwork, we found that the inflorescence of this species has 1 3 umbels that are borne on a common axis, and $1-2$ nodes with a bract at the base of each umbel peduncle. This matches well with $S$. perfoliata and we conclude that $S$. ocreata should be regarded as conspecific with $S$. perfoliata. Strachey $\mathcal{E}$ Winterbottom 5 (K000820890) is selected as the lectotype of S. ocreata because it has many male flowers and fruits and also has complete leaves and petiolar sheaths that show their variation.

11. Smilax prolifera Roxb. (Roxburgh 1832: 795). Type: India, Wallich 5124B (lectotype K, selected by Koyama (1983), emended here to K-W! [K001104859]; isolectotypes K-W! [K00110486], P! [P00686844]).

Smilax siamensis T. Koyama (1974: 136). Type: Thailand, Kanchanaburi, Sai Yok, 11 Feb. 1959, 충, Sangkhachand 767 (holotype NY! [NY00320038]; isotypes BKF, K!, L).

NOTES. The original description of Smilax prolifera was published by Roxburgh (1832). However, this species was treated as a synonym of $S$. perfoliata by Chen \& Koyama (2000) and Dassanayake (2000). On examination of type material of $S$. prolifera and specimens collected during fieldwork, we found that the inflorescence of this species has 7 - 30 umbels that are borne on a common axis and 3-8 nodes with $1-3$ umbels per node subtended by only one bract. These characters define the proliferous inflorescence that was alluded to in the specific epithet prolifera by Roxburgh (1832). Therefore, we conclude that $S$. prolifera should be regarded as species in its own right. The lectotype of $S$. prolifera was selected by Koyama (1983), but Wallich 5124B has three duplicates, the sheet $\mathrm{K} 001104859$ at K-W is selected here as the lectotype because it has many complete male inflorescences.

\section{Acknowledgements}

We are grateful to the Curators, Keepers, Librarians and staff of all herbaria visited for access to material in their charge and the Department of Biology, Faculty of Science, Khon Kaen University for their facilities. The first author thanks the Royal Golden Jubilee Ph.D. Program (grant no. PHD/0173/2557) under the Thailand Research Fund for financial support.

Open Access This article is distributed under the terms of the Creative Commons Attribution 4.0 International License (http://creativecommons.org/licenses/by/4.0/), which permits unrestricted use, distribution, and reproduction in any medium, provided you give appropriate credit to the original author(s) and the source, provide a link to the Creative Commons license, and indicate if changes were made.

\section{References}

Cameron, K. M. \& Fu, C. X. (2006). A nuclear rDNA phylogeny of Smilax (Smilacaceae). Aliso 22: 598 - 605. 
Candolle, A. de (1878). Smilacées. In: A. de Candolle \& C. de Candolle (eds), Monographiae Phanerogamarum Prodromi 1: 1 - 217. G. Masson, Paris.

Chen, S. C. \& Koyama, T. (2000). Smilax. In: C. Y. Wu, P. H. Raven \& D. Y. Hong (eds), Flora of China (Flagellariaceae through Marantaceae) 24: 96 - 117. Science Press \& Missouri Botanical Garden Press, Beijing \& St. Louis.

Qiu, Y. X., Wang, A. L., Cameron, K. M. \& Fu, C. X. (2006). A phylogenetic analysis of the Smilacaceae based on morphological data. Acta Phytotax. Sin. 44(2): 113 - 125.

Craib, W. G. (1912). Contributions to the Flora of Siam. II. List of Siamese Plants, with descriptions of new species. Bull. Misc. Inform., Kew 10: 397 - 435.

Dassanayake, M. D. (2000). Smilacaceae. In: M. D. Dassanayake \& W. D. Clayton (eds), A Revised Handbook to the Flora of Ceylon 14: 272 - 276. Oxford \& IBH Publishing Co. Pvt. Ltd., New Delhi.

Gray, A. (1858). Diagnostic characters of new species of phanogamous plants, collected in Japan by Charles Wright. Mem. Amer. Acad. Arts, n.s. 6(2): 377 - 449.

Heywood, V. H., Brummitt, R. K., Culham, A. \& Seberg, O. (2007). Flowering Plants of the World. Kew Publishing.

Hooker, J. D. (1892). Liliaceae. In: J. D. Hooker (ed.), Flora of British India 6: 320 - 314. L. Reeve \& Co., London.

Judd, W. S., Campbell, C. S., Kellog, E. A., Sterens, S. P. F. \& Donoghue, M. J. (2016). Plant Systematics, a Phylogenetic Approach 4th Edition. Sinauer Associates Inc., Sunderland, Massachusetts.

Koyama, T. (1960). Materials toward a monograph of the Genus Smilax. Quart. J. Taiwan Mus. 13(1): 1 - 61.

(1963). The Indian species of Smilax. In: L. Chandra (ed.), Advancing Frontiers of Plant Sciences 4: 39 - 77. Institute for Advancement of Science and Culture, New Delhi.

(1971). Smilax. In: H. Hara (ed.), Flora of Eastern

Himalaya. Bull. Univ. Mus. Univ. Tokyo 2: 171 - 173. (1974). Four new species of Smilax (Smilacaceae) from South-eastern Asia. Brittonia 26(2): 133 - 138. (1975). Smilacaceae. In: T. Smitinand \& K. Larsen (eds), Flora of Thailand 2(3): 211 - 250. Applied Scientific Research Corporation of Thailand, Bangkok.
(1983). Smilacaceae. In: Jean-F. Leroy (ed.), Flore du Cambodge, du Laos et du Viêt-Nam 20: 69 - 124. Muséum national d'histoire naturelle, Laboratoire de phanérogamie, Paris.

(1984). A taxonomic revision of the genus Heterosmilax (Smilacaceae). Brittonia 36(2): 184 - 205.

Kunth, K. S. (1850). Smilaceae. In: K. S. Kunth (ed.), Enumeratio Plantarum Omnium Hucusque Cognitarum 5: 159 - 272. Sumtibus J. G. Gottae, Stutgardiae, et Tubingae.

Loureiro, J. (1790). Smilax. In: J. Loureiro (ed.), Flora Cochinchinensis 2: 621 - 623. Typis, et expensis academicis, Ulyssipone.

Mabberley, D. J. (2008). Mabberley's Plant-book: a Portable Dictionary of Plants, Their Classification and Uses, 3rd Edition. Cambridge University Press, Cambridge.

Merrill, E. D. (1922). New or Noteworthy Bornean Plants. J. Straits Branch Roy. Asiat. Soc. 85: 151 - 201. (1935). A commentary on Loureiro's "Flora Cochinchinensis". Trans. Amer. Philos. Soc. 24(2): $109-110$.

Moore, B. R., Narkkong, N., Moore, T. \& Lutal, P. (2008). Epicuticular leaf architecture confirms a new Smilax species (Smilacaceae) from Northeast Thailand. Science Asia 34: 103 - 106.

Presl, C. B. (1827). Smilacaceae. In: C. B. Presl (ed.), Reliquiae Haenkeanae 1(2): 131 - 132. Apud J. G. Calve, Pragae.

Qiu, Z., Cameron, K. M., Li, P., Zhao, Y., Chen, X., Chen, G. \& Fu, C. X. (2013a). Phylogenetics, character evolution, and distribution patterns of the greenbriers, Smilacaceae (Liliales), a nearcosmopolitan family of monocots. Bot. J. Linn. Soc. 173: $535-548$.

, Li, P. \& Fu, C. X. (2013b). New combinations and a new name in Smilax for species of Heterosmilax in Eastern and Southeast Asian Smilacaceae (Liliales). Phytotaxa 117(2): 58 - 60 .

Rae, S. J. (1994). Smilacaceae. In: H. J. Noltie (ed.), Flora of Bhutan 3(1): 24 - 36. Royal Botanic Garden, Edinburgh.

Roxburgh, W. (1832). Smilax. In: W. Roxburgh (ed.), Flora Indica Vol. 3: 791 - 796. Printed for W. Thacker, Serampore. 